\title{
Plato's Puppets of the Gods: Representing the Magical, the Mystical and the Metaphysical
}

\author{
KENNETH ROYCE MOORE
}

\section{M} pends on argument by analogy for the explanation of his doctrines; "this was because he treated so largely of the unseen and intangible." I Starting in book I of the Laws, and referenced elsewhere, Plato's Athenian Stranger introduces an extended metaphor whereby human beings are likened to "puppets of the gods" or "divine marvels" (thauma ... theion). ${ }^{2}$ Occurring in the context of theorizing about law, this is a key element of an unusually metaphysical discussion within a text that, on the surface at any rate, deals less in metaphysics than earlier works, although it frequently alludes to, and presupposes, an understanding of Platonic philosophy and metaphysics. The aim here is to examine this cryptic metaphor in context and in the light of relevant scholarship in order to unpack its significance. It touches on a number of subjects ranging from Plato's concept of the controlled drinking party and issues surrounding sexual desire to the broader workings of the psychê. On the one hand, it functions within the realm of Platonic metaphysics regarding representation and, as such, connects with the Theory of Forms. On the other, it partakes more broadly of ancient Greek and Near Eastern traditions concerning puppetry and its place in religious and mystical rites. Appropriate to both of these topoi, the allegorical "puppets of the gods" motif entails a number of Pythagorean elements as well.

This metaphor is introduced at Laws $644 \mathrm{~d}_{7}$ ff. Plato's Athenian Stranger is discussing the impact on human beings

ARION 22.2 FALL 2OI4 
II 2 PLATO'S PUPPETS OF THE GODS

of expectations about the future, fear, and calculation. The last one of these, (logismos), also renderable as "reckoning," is identified with Reason's "golden cord" that guides the psychai of mortals along the correct path.3 "When logismos has become the dogma of the polis," says the Athenian Stranger, "it is named nomos [law]." 4 His interlocutors request further elaboration and he says:

Let us conceive of it in the following way. Let us suppose that each of us living creatures is a puppet of the gods, whether contrived as some kind of toy or for some serious purpose; for as to that we know nothing, but we do know that these inner affections of ours, like sinews or cords, drag us along and, being opposed to one another, pull against each other in opposing actions. And herein resides the dividing line between good and evil. For, as our argument declares, there is one of these pulling forces which every person should always follow and in no way leave hold of, counteracting thereby the pull of the other cords. It is this leading golden and holy string of calculation that is titled the public law of the state. 5

The Laws is dominated by the notion that the (true) lawgiver is divinely inspired and that the law itself is the work of divinity. ${ }^{6}$ The word translated as "puppet" here, thauma, literally means "marvel." 7 And a thauma theion would be some kind of "divine marvel" or a "marvel of the gods"; although, from the context, it is clear that he is referring to puppets, or specifically marionettes, about which I shall discuss more below. In this metaphor, a recognizable Platonic formula emerges whereby one who yields to the baser "iron" cords is considered "self-inferior" and one who obeys the "golden cord" is "self-superior." 8 The baser ones are of iron, presumably because, unlike gold, iron rusts; and he may also be making an offhanded allusion here to Hesiod's degenerate Age of Iron in the Works and Days. 9 This psychological theory, and its tangible illustration in the fable of the puppets, illuminates the nature of "self-mastery" that has been promoted as a paradigm for virtue since the inception of the dialogue $\left(626 \mathrm{e} 2-6,633 \mathrm{~d}_{5}-\mathrm{e} 6\right)$. Victory over 
one's self, even if apparently paradoxical prima facie, amounts to victory of the "better" part of the psychê over the "worse" (626e7-627 4 ). ${ }^{\text {10 }}$

While Plato's "puppets of the gods" metaphor represents fundamental features of his philosophy, it also entails numerous layers of complexity not readily accessible to the modern reader. In order to better appreciate this metaphor, firstly, some insights into ancient puppetry, contemporary with Plato's era, are essential. Ancient Greek puppets appear to have come in at least four types: shadow puppets, stick puppets, marionettes on strings, and more complex marionettes, also controlled by a puppeteer using strings or cords. All of these have Near Eastern origins apart, perhaps, for the last one which may have been a wholly Greek invention, albeit derived in part out of earlier, foreign traditions. In the $6^{\text {th }}$ century $\mathrm{BC}$, Persian magi came into Greece and used puppets in their rituals, which soon began to resemble those of the indigenous mystery cults. ${ }^{\text {II }}$ It is difficult to tell which tradition most influenced the other in this respect; it may have been wholly mutual. Greek puppetry may also have been influenced by other Near Eastern mystical practices. Herodotus refers to Egyptian women engaging in orgiastic fertility rituals with what he calls "Dionysiac" puppets (thauma). He describes these as "two feet long, moved by strings, which are carried about the villages by the women, with the male member moving and nearly as big as the rest of the body." ${ }_{2}$ We also have evidence from the Classical period of sorcerers using shadow puppets for public performances of their magic. ${ }^{13}$ These varied from harmless spectacles or "marvels" (the name often used for puppets, thauma, pl. thaumata) to blessings and curses. Greek puppets were not exclusively for ritualistic operations but no less still bore mystical significance inasmuch as they often represented individual gods and heroes who were sacred. ${ }^{14}$ Shadow puppets and marionettes were both used in dramatized scenes from the Iliad and Odyssey. Though these shows would have been aimed largely at an audience of chil- 
II4 PLATO'S PUPPETS OF THE GODS

dren, the religious connotations of such representations would seem apparent, given the subject matter.

Ancient puppets could be fairly sophisticated in design. Aristotle describes the working of $4^{\text {th }}$ century marionettes, saying that "the movements of animals may be compared with those of automatic puppets, which are set going on the occasion of a tiny movement; the levers are released, and strike the twisted strings against one another." ${ }^{5}$ This and other passages from Aristotle have led some to believe that Plato's "puppets of the gods" must be some type of wind-up automata rather than marionettes, which has been the dominant view to date. Annas writes that "Plato is thinking, not of puppets on strings, but of toys which move around by themselves (a kind of clockwork wind-up toy)." ${ }^{16}$ She derives this in no small part from the work of Berryman who has demonstrated that such things existed, at least from Aristotle's era onwards, and which could also be referred to as thaumata. ${ }^{17}$ If it were the case that Plato meant "clockwork wind-up toys," then it would seem to bear out the analogy to a point inasmuch as human beings with souls are self-moved movers rather than puppets animated by an external, physical agency. However, for Plato the psychê is a manifestation of divinity and animates human bodies in much the same way as a puppeteer might do with his thauma. Berryman herself cites a shift in significance of the puppet model in later antiquity, from an image of self-movement to one of simply mechanical, automatic movement. ${ }^{18}$ Clockwork automata are not self-moved movers. They are clearly set in motion by something else, crucially, to which they are not still connected. For Plato, the psychê itself, or that aspect of it that is connected to divinity, is the puppeteer, its "golden cord" directly partaking of the Form of the Good, insofar as such unexpressibles may be put into words.

For the analogy in the Laws to work, especially given that there are various "strings" or "cords" involved, pulling sometimes in different directions, a marionette would seem to be the more appropriate image rather than a wind-up toy. 
The Athenian Stranger says that his thauma is pulled by neura or mêrinthoi. LSJ define neura (singular neuron) as "strings" or "cords of sinew"; mêrinthoi are "cords, lines or strings." I9 Neura can also refer to the tendons of the feet, cords made of sinew used for stringing bows as well as, more metaphorically, the "sinews" or "vigorous" strains of rhythm in lyric odes. The musical double-meaning is perhaps intentional given the Athenian Stranger's frequent play on the word nomos, meaning both "law" (as in the title of his treatise, Nomoi, the Laws) and "musical note." 20 It would therefore not be too much of a stretch in referring to them as "chords" rather than "cords," keeping the word play in English. The "golden c(h)ord," then, might be a reference to the Pythagorean "golden ratio" that produces the "harmony of the spheres" and connects with a host of other notions consonant with Plato's analogy here. ${ }^{21}$

It is possible that ancient Greek wind-up toys had strings, acting as sinews, in order to articulate their limbs comparable to those attached to a marionette. However, these would have been purely functional, within the automaton and likely not pulling the toy in different directions from an external source. Even so, I do not dismiss Annas' claim outright because Plato may be referring to a sophisticated type of puppet (neurospaston) that had internal strings, recalling the "inner affections" to which the cords are compared in his metaphor, acting like human sinews. But they would still have been animated by external agency, whether from above or on the same level, from a kind of control box operated by a puppeteer. ${ }^{22}$ These were truly "marvels" and were of special interest to the Roman-era physician Galen: "This is the device, I believe, that is used in moving [images] with cords; for passing over their articulations, the cords are fastened to the beginning of the parts beyond, so that the [images] readily obey the force of the upward pull when the cords are tightened." 23

This kind of puppet would have been most similar to a human being, in terms of anatomical likeness, and capable of mimicking human movements in a realistic manner. Plato 
I 6 PLATO'S PUPPETS OF THE GODS

does not appear to be referring to wind-up automata here. A puppet or marionette necessitates a puppet master and, in the case of that which pulls the golden cord (or chord), it is the Form of the Good, via the psychê, albeit having to compete with the "iron strings" of the appetites.

We have other examples of marvels of a comparable nature. The god Hephaestus was said to have produced a number of automata. ${ }^{24}$ Pindar's seventh Olympian Ode describes animated "images" from Rhodes and Crete "like living, moving creatures, and their fame was profound." ${ }_{25}$ Plato himself discusses moving statues said to have been constructed by the mythical Daedalus. ${ }^{26}$ Aristotle reported that Democritus described statues that were made to move by pouring quicksilver, analogous to the human psyche $\hat{e}$, into them. ${ }^{27}$ If such a thing existed, it may have been moved by magnets. And, although after Plato's era, Pliny the Elder describes a statue of iron, another "marvel," suspended in space by magnets at the Temple of Arsinoe in $3^{\text {rd }}$ century вС Alexandria. ${ }^{28}$ In the same city, but in the $\mathrm{I}^{\text {st }}$ century AD, we have Hieron's "programmable" moving cart, along with other moving statues that used pneumatics, which were probably based on earlier work by Archimedes.29 All of these may be referred to as thaumata, "marvels" or thaumatapoioi, which "encompasses conjuring, acrobatics, juggling, and marionette-shows or, in other words, any kind of performance that produced baffled amazement in spectators." ${ }^{\circ}$ But none quite seem to fit the description of Plato's thauma in the Laws as well as that of the complex marionette, the neurospaston, assuming that it existed in his lifetime and that he was aware of it in some capacity.

TWO OTHER INSTANCES of puppets recur in the Laws. In the first of these, Plato's narrator is not using the "puppets of the gods" metaphor per se but merely associating puppetry with activities that induce base pleasure. At $658 \mathrm{c}-\mathrm{d}$, the Athenian Stranger discusses regulations on public performances. He says that if there were no limits imposed on the type of per- 
formance, and the greatest prize were to be given to that which provokes the greatest pleasure in the audience, then a puppet show might win out over a Homeric rhapsode, however skilled. If children were the judges of such a competition, they would certainly award the highest prize to the puppet show $(658 \mathrm{CII}-\mathrm{I} 3)$. He concedes that a musical performance ought to give pleasure; but, it should be a carefully controlled type of pleasure that wins out over baser kinds. Letting the uneducated judge such things corrupts both them and the performance itself, which will then always incline towards the baser elements of entertainment. Only the educated can judge correctly and the Athenian Stranger defines education here as "guiding children towards that principle which is pronounced correct by law" (ton bupo tou nomou logon orthon) and confirmed by their elders who are the most just. ${ }^{\mathrm{I}}$ The definition of a just man here, much as in the Republic, is concomitant with Reason's rule of the psychê. So, in (re-)admitting the representative arts into his Magnesia, Plato imposed strict regulations on them and, as with the puppet metaphor, he linked correct and acceptable performative behavior with law and the rule of Reason.

The final reference to puppets in the Laws (804b) does directly allude back to the earlier metaphor of human beings as "puppets of the gods" and illustrates how a skillful legislator can utilize this feature of human psychology in order to achieve philosophically motivated ends. It also reveals that, as is suggested in the discussion of controlled symposia (see below), not all such "puppets" are necessarily capable of following the "golden cord" without some outside assistance. The Athenian Stranger is here deliberating over the types of acceptable pastimes for his hypothetical Magnesians and these will include sacrificing, singing, and dancing, which will allow them to "win divine favors and also to repel and defeat enemies in battle." ${ }^{2}$ Magnesian boys and girls will put on armor and perform choral dances both to entertain the public as well as to hone their fighting skills. 33 These armed performances are derived in part from the Kretan games of ar- 
I 8 PLATO'S PUPPETS OF THE GODS

mor of the Kuretes, the games of the Spartan Dioskuri (Kastor and Pollux), and those of Athena the Virgin at Athens.34 There are two kinds of dances identified in the Laws as beautiful and good: the warlike Pyrrhic and the peaceful Emmeleia. The Pyrrhic variety, which represents the "motion of fighting, and ... of fair bodies and brave souls engaged in violent effort," is specifically considered to promote courage; the Emmeleia, or pacific dances, signify "the motion of a temperate soul living in a state of prosperity and moderate pleasures" and, as such, this type promotes the underlying morality of Magnesia.35 Indecent dances are identified as those that concern ugly bodies and reflect negative mentalities along with those that incline one towards comic laughter. ${ }^{36}$ Aristotle was critical of Plato's insistence in this regard on a kind of moderation that approached austerity in the Laws, saying that it would be better to live both "with moderation and liberally" as well.37 The plan for Magnesia compares well with the musical education outlined in the Republic and generally follows Socrates' discussion there. $3^{8}$ Different types of music were regarded, not just by Plato but by the ancient Greeks more broadly, as promoting certain character types and feelings. Some varieties of the Lydian mode were seen as mournful, the Ionian relaxing, and, more importantly here, the Dorian and Phrygian have been considered by Plato's narrators to inspire self-control and courage. 39 The use of music to influence human emotions and behavior also, we are told, interested the Pythagoreans. $4^{\circ}$

The rhythms and modes of musical accompaniment for the Magnesian performances are designed to impart appropriate characteristics through the process of imitative learning. This is "serious play" designed to condition the citizens to have respect for religion as well as martial values $(803 \mathrm{~d} 2-3)$. It is also a type of social engineering based on Plato's understanding of human psychology. The Athenian Stranger indicates that, backed by religious indoctrination, these games will "thus mould their lives according to the shape of their nature, insofar as they are puppets for the 
most part, but partake occasionally of the truth." ${ }^{\text {I }}$ His Spartan interlocutor, Megillus, comments at this point that the Athenian Stranger must have a very low opinion of the human race to require so much compulsion for good behavior. He counters, saying that his mind was on divine matters and that he was swept up by emotion during this discussion but that humanity is not really so mean. Even so, compulsion remains a principal tool that will be used to encourage correct behavior. The citizens should always make decisions guided by the "golden cord" of wisdom, and while this is to be aimed at, some will require coercion no less. ${ }^{2}$ The institutions and laws of Magnesia, their preambles, and the system of education itself will "enchant" the subjects, working a kind of counter-magic against negative impulses. 43

THE "PUPPETS OF THE GODS" METAPHOR in the Laws recalls the myth of the Two Horses in the Phaedrus (246b ff.) and should in all likelihood be read with regard to it. The latter specifically offers an analogy of the effects of erôs on the psychê. All of the Platonic corpus, perhaps abridged appropriately to the level of the reader, will be required reading in the hypothetical Magnesia of the Laws, and the puppets metaphor would appear to be an intertextual reference to the two horses myth.44 The descriptions of erôs from the Symposium and the Phaedrus remain consistent throughout Plato's works. There is also evidence that the Phaedrus itself may have been written fairly late in Plato's life and, as such, would have been developmentally closer to the Laws.45 It is noteworthy too that this narrative on erôs comes as part of a greater discussion by Socrates on the immortality of the soul-which resurfaces at Laws 7r4a, 894b ff. and $966 \mathrm{~d}-967 \mathrm{~d}$, and is metaphysically connected with the puppets metaphor.47

In the Phaedrus myth, the human psychê is likened to two winged steeds being steered by a person in a flying chariot. The souls of gods are considered altogether good and free from any discord. But humans are afflicted by erôs, which is always in a discordant state between Want and Resource. 
I2O PLATO'S PUPPETS OF THE GODS

Thus it is deemed to be some kind of lesser spirit in the Symposium. The souls of mortals, by contrast, have these two "horses" of which one is wholly good and noble and the other possesses the opposite inclinations (246b). They generate Strife between them-one tending toward the Good and the other toward its opposite. When, for instance, one beholds a "lovable vision," the other contemplates using force (thus the presence of bybrizein at $253 \mathrm{e} 3$ ), desiring to "leap on" the beloved (254a2-3). Such urges, apparently irreducible in human beings, must be vigorously suppressed and "modest restraint" must prevail. But our darker side (typified by the "black horse") will also try seduction, approaching the attractive youth, attempting to persuade him with the pleasures of sex, the "things of Aphrodite." 47 Again, there is a clear sense of "self-inferior" and "self-superior" depending on which metaphorical horse gains the lead.

This duality within the soul generates conflict and presents a problem for the "charioteer" trying to steer his soul aright. The two principles of action distinguished within it are an innate desire for pleasures (epithumia) and an acquired judgment (doxa) which aims at what is best. $4^{8}$ These two psychical forces may agree or, more often, be in dispute; if the latter, then one or the other will prevail.49 When good judgment has mastery, it leads the soul toward that which is rationally "best." This is synonymous with self-mastery and moderation (sôphrosynê). The rule of the opposite inclination, desire for indulgence in "base" things, drags the soul irrationally toward the perpetual and compulsive gratification of excessive desires. $5^{\circ} \mathrm{A}$ definition of erôs thereby arises from the Phaedrus in the following words of Plato's Socrates:

For when Desire (epithumia), having gained mastery in the absence of logical judgment (which urges one toward what is right), bears one toward pleasure with regard to beautiful things, and, in turn with desires kindred to itself, it then rushes on the beauty of bodies, conquering in its mode of conduct, taking its name from the force itself-this is called erôs. ${ }^{\mathrm{I}}$ 
The dominance of erôs may thus be construed as a "state in which a certain species of desire prevails over Reason." ${ }_{52}$ These rival impulses always threaten to distract and confound the lover. 53 There is here a sense of the intellectual limitations-a lack of calculation-to be found in the lower parts of the psyche that is more consistent with the bipartite model of the soul found in the Laws (as opposed to the tripartite model of the Reason-ruled, the Honor-loving, and the Appetitive parts in the Republic). The horse that represents the appetites is "shaggy-eared, devoid of sense and barely yielding to the whip and goad together" (235e4-5). And, as Bobonich indicates, "it is trained only by the use of force, not by words of command." 54 This recourse to compulsion in order to rein in the appetites, as we have seen, is compatible with the plan to encourage the human "puppets" in the Laws to follow the lead of the "golden cord."

In that text, the Athenian Stranger describes a virtually identical situation in which a lover wishes to enjoy the pleasures of his beloved whilst his Reason at the same time forbids it. One who craves the body of his beloved "as if he were so much ripe fruit" (hôras kathaper opôras-note the pun) does so "without giving a thought to the character of his darling's soul." 55 Desire can have as its object either Beauty/the Good or something "base" and "bodily." Judgment may, of course, rein in "improper" yearnings (which, if left unchecked, encourage a state of yielding to excess) and beget wisdom in one through "divine philosophy." ${ }^{6}$ However, Phaedrus $237 \mathrm{~d}_{4-5}$, recollecting Diotima's speech in the Symposium (204b ff.), argues that all desire is really desire for the Beautiful/Good-however misdirected or otherwise. The "horse" that inclines against the Good (an agent of Strife) corresponds to the mortal part of human beings that fails, through ignorance and through not surpassing its own limitations, to be attracted to the proper object-namely, the Beautiful/Good.

Any form of erôs, even that which desires the Good as its object, still has the dubious distinction of being a type of 
I22 PLATO'S PUPPETS OF THE GODS

"madness" (manias).57 This is potentially problematic because the definition holds not only for human love-objects, but a comparable form of manias is also positively associated with both philosophy and mystical practices. Its convergence with nous in erôs is intriguing and has some bearing on the mystical attributes of puppetry, to which I shall presently turn. $5^{8}$ Pieper objects to "madness" as the meaning of manias here due to the fact that it "suggests ties with the orgiastic Dionysian rites." 59 However, this was apparently not a problem for Plato. There is ample evidence that such orgiastic, Dionysian rites were agreeable to his narrators. Indeed, the Athenian Stranger even recommends a sort of "Dionysiac treatment" for mothers to use in putting babies to sleep at Laws $790 e$, and, at Republic $479 \mathrm{~d}-\mathrm{e}$, Socrates informs Glaucon that the revelers at Dionysiac festivals bear a certain likeness to philosophers. This issue has also been touched upon at Symposium 2 I 8b, inasmuch as Phaedrus, Agathon, Eryximachus, Pausanias, Aristodemus, Aristophanes and Socrates are all said to have had a taste of this philosophic species of Bacchic "madness." In the Laws, we have a comparable instance in which the Athenian Stranger praises "divine erotic passion" (erôs theios) for producing prudence and justice that, again, seems to stand awkwardly alongside the negative manifestations of manias (7I Id6 ff.). We are left with a conceptualization in which one type of madness is acceptable and another is not. Nonetheless, it is clear in the Phaedrus that the rule of the appetites in the soul is seen as a particularly malevolent variety of manias.

Madness is one altered state that interested Plato, with both positive and negative implications; intoxication is another. The puppet metaphor in the Laws is applied directly to Plato's plan for controlled drinking parties (or educational symposia) and, at $645 \mathrm{~d}$, he asks what the effects would be on such a "puppet" if given an intoxicant such as alcohol. The idea is to test and condition an individual's resistance to the baser "cords" when their inhibitions are lowered and thus, by extension, to enhance their self-discipline 
when sober. The hypothetical Magnesians are not permitted to partake of alcohol until the age of eighteen and are encouraged to drink only in moderation until old age, after which they are granted somewhat greater latitude. 60 In fact, the elderly are encouraged to drink more or less as much as they please, as a kind of comfort in old age, and also to sing together whilst drunk.

The controlled drinking party is an institution designed to inculcate rational restraint. It will educate the citizens into being courageous in the face of physical danger and also to discourage them from illicit pleasures. ${ }^{61}$ A good legislator can make a person proof against all manner of negatively identified things, says the Athenian Stranger, "by putting him into a state of fear within the strictures of law" $(647 \mathrm{c} 3-4)$. This is half the battle. The subjects may overcome cowardice when faced with peril but must also learn to be moderate and have self-control sufficient to stave off the desires for activities deemed shameless, which include such erotic excesses as identified in the Phaedrus myth and elsewhere.62 The educational symposia are to promote the official values associated with sôphrosynê (moderation) and to encourage andreiacourageousness, specially defined here as proof against both fear and temptation. In keeping with the overall educational theme of Magnesia, three powerful forces will be brought to bear in achieving this: fear, shame, and calculation (logis$m o s)$. The Athenian Stranger notes that drunken individuals sometimes require strong, negative reinforcements, such as the threat of displeasure from authority-figures, along with the public reproach that this may accrue, in order to behave properly. If a reveler is not willing "to obey those [in charge] and the officials of Dionysos, who are aged upwards of sixty years, then he must bear shame equal to and greater than those who are disobedient to the commanders who are the officials of Ares, the god of war." ${ }_{3} 3$ Shame, through dishonor (or the threat thereof), figures prominently in the equation and is part of the compulsion that will be used to ensure that the puppets heed the pull of the golden cord. ${ }^{64}$ 
I24 PLATO'S PUPPETS OF THE GODS

THIS PUPPET METAPHOR connects with other features of both Platonic metaphysics and mystical beliefs regarding representation which reveal it in a different light. In order to approach it, we must first consider what Plato and others thought about puppetry, qua representation, and the implications thereof. Puppets' close semblance to living things, and the mystical traditions associated with them, troubled the great philosopher. This is borne out in a number of instances and the connection between puppets and magic is amply present here. Puppets were seen as connected somehow to that which they represented; and representation itself was considered to entail magical qualities.

Despite his anxieties over the dangers of (mis)representation, Plato made frequent recourse to analogies, metaphors, and the arts of representation-although, in his hands, we presume, these would have been safely administered. Not so by others. In the Sophist, he writes: "what can be the secret of this magical power (thauma) of sophistry?" $65 \mathrm{He}$ is not talking about puppets here but uses the same term that he has employed elsewhere for them, thauma, in the context of sophistic persuasion, itself relying on representational legerdemain, and implying a kind of magical quality about it. Picking up on the aforementioned use of puppets in mystical rituals, Socrates in the Republic refers to "soothsayers" who "are masters of spells and enchantments that constrain the gods to serve their ends." 66 They do so with representative images of these, given that representation itself was considered to have had profound magical connotations. This extends to drama in particular and, again in the Republic, we are told that "the painting of scenes is nothing short of witchcraft, and so too is jugglery and many other such contrivances." ${ }_{7}$ The shadow puppets, a secondary metaphor used in the Myth of the Cave (Rep. 5I4b ff.), accrue negativity since they are being used to fool the inmates into thinking that they are seeing what is real, when they are only seeing shadows of representations at best. ${ }^{68}$ In the Laws, the Athen- 
ian Stranger even legislates against the magical practice of doing harm to others by means of wax manikins, ancient precursors of voodoo dolls, set up in the victim's doorway. 69

This last reference, along with other passages from the Republic and the Laws, have led some scholars, like E. R. Dodds, to maintain that Plato was skeptical of magic and sought to stamp it out, perceiving it as a threat to society. 70 Indeed, the prohibition against using magic to cause harm to others in the Laws was later deployed in support of the persecution of many so-called witches in the Early-Modern era. Dodds says that Plato was "one of the very few ancient writers who had the intellectual courage to express scepticism on that subject," and he even goes as far as to maintain that he lacked any "serious belief in the personal gods of Greek mythology and Greek cult," despite Wilamowitz-Möllendorf's tentative assertion to the contrary. ${ }^{71}$ In keeping with the Zeitgeist of his own era, Dodds considers Plato to have been "agnostic" on the matter; and yet, both the "puppets of the gods" metaphor and other issues more generally surrounding representation suggest otherwise. Plato's whole philosophical project in the Laws is grounded in a magisterial assertion that truth must control representation rather than vice versa. ${ }^{2} \mathrm{He}$ also appears to have believed that representations could be magically deployed in order to alter and affect reality. A representation somehow "partakes" of that which it represents in much the same way as earthly particulars "partake" of the Forms. The two are seen as connected and the manipulation of one is thought to influence the other. This is a basic definition of sorcery, and one which our own Age of Reason sought to dispel but which has resurfaced in more modern theories of gravitation and quantum entanglement: action at a distance. It is impossible to know what Plato believed, but his writings suggest some kind of acceptance of the magical as well as an advanced ethical position concerning its use. Plato's treatment of the dramatic arts particularly illustrates his obsession with the magical powers of representation-and there too we find more puppets. 
I26 PLATO'S PUPPETS OF THE GODS

In Athenian dramas, and presumably throughout the whole of ancient Greece, a statue of a god would be lowered onto the stage by a crane (mechanê) when its presence was required in the play. It is somehow appropriate that our best source on this happens to be Plato.73 His Socrates in the Republic criticized what he considered to be inappropriate representations of the gods by poets as both blaspheming and setting bad examples for the young $(377 \mathrm{e}-392 \mathrm{c})$. There is every reason to believe that dramatic representations of the gods as suspended statues would have equally concerned him. When the god was thus represented, an actor behind the scenes would sonorously chant its lines, imparting to it a further, super-human quality. This appears to have been the rule for most plays; although in Aristophanes' Frogs and Euripides' Bacchae, an actor would have played the role of Dionysus in most scenes. In the latter play, a suspended statue would have probably been used for Dionysus in the denouement when he drops his human guise and metes out his judgments and punishments. A statue of a god on a crane is strikingly similar to a puppet or marionette on strings; although we do not know if these were also articulated for movement, it would not be surprising if they were. Representing the god as a kind of puppet symbolically draws the deity into the scene and at once lends an appropriate degree of divine distance to it as well, since it is not then played by a human actor. Given that Athenian stage drama itself transpired within a religious context, there is every reason to expect that these instances of the deus ex machina would have been regarded as partaking of the realm of the supernatural.

The fact that Plato has chosen to remark on this phenomenon in two dialogues, albeit in passing, alludes to his keen interest in, and apprehension for, mimetic drama. His concern with representation is clearly observable in the Republic where his Socrates bans it altogether (398a). Drama is re-admitted in the Laws, but only under the strictest of rules governing what and who may or may not be represented and in what permissible manner. Representation, like the 
sophist's speech, has the power to change people's minds. It is in no small part on account of their innate diversity of potentially conflicting messages in their representations that popular dramatic performances and emotive poetry are at odds with the state-espoused ideal of "masculine unity" in the Laws.74 The perceived feminine quality of poikilia, "multiplicity" or "multifacetedness," which makes women's experience and behavior a particularly interesting subject for drama, is deemed a potentially hazardous moral example. 75 And yet, Plato appreciated that drama has an educative potential which makes it too useful to dispense with altogether.

The Athenian Stranger in the Laws recognized, long before Chomsky, that learning institutions and contexts may serve as an effective "filtering system for alternative truths," although he probably would not have acknowledged that there could be any "truth" other than the Truth per se. ${ }^{76}$ The inclusion or exclusion of given ideas in accredited schools and the representative arts allows the polis a powerful lever with which to exert control over meaning and, hence, thought. The Athenian Stranger applies this principle of ideological censorship to most aspects of his educational programme. Potentially "dangerous" subjects merit the most intense regulation by Magnesian legislators in a manner almost identical to that of the Republic. In both it and the Laws aesthetics and the mimetic arts are subordinated to a morality that serves a rigidly-defined ontological notion of the cosmos and its incumbent metaphysics. 77

There is a notable change in his position, however, inasmuch as some dramatic modes are to be granted a degree of legitimacy in the second-best state that were altogether excluded from Kallipolis. ${ }^{8}$ A solution had to be found to address the problem of dangerous representations. The censorship of drama and literature will be one of the most pervasive means of compulsion used on Magnesia's human "puppets." Foreign dramatic performances in particular will be highly suspect and safeguards will be employed against the threat of external artistic influences that could "damage" the Magne- 
I28 PLATO'S PUPPETS OF THE GODS

sians' psychai. These hypothetical citizens will assiduously study their own laws as a means of improving civic virtue and to develop and enhance their ability to discern logo $i$ with the aid of philosophical reason $(957 \mathrm{c}-\mathrm{d})$. This will provide them with an "antidote" or "magical potion" (alexipharmakon) against alien discourses, and it echoes Socrates' statements on the nature of written texts as pharmaka that influence the psychê in the Phaedrus.79 The Magnesians will memorize much of the law code and study the official canon of literature (the Platonic corpus) since these will serve as a perpetual standard against which all other modes of discourse and thought are to be measured. ${ }^{\circ \circ}$ The term pharmaka has decidedly magical connotations and here Plato is using it, both metaphorically and literally, to counter the "bad magic" implicit in negative representations. ${ }^{8 \mathrm{I}}$

As part of their education, it will be necessary for Magnesia's citizens to learn about comedy so that they know to avoid imitating such ludicrous behavior themselves. ${ }^{82}$ In the Republic, Plato apparently did not think that watching comedies could help in learning the nature of base and ridiculous characters. ${ }^{8} 3$ However, his Socrates does indicate there that it is necessary for the citizens of the Kallipolis to know about "base" and "mad" people so as to avoid imitation of them, and this policy has been further expanded for Magnesia. ${ }^{84}$ The rationale in the Laws is scrupulously didactic and, as Golden aptly puts it, comedy is permitted only because of "the necessity of learning the nature of the noble through the nature of its opposite, the ridiculous." ${ }_{5}$ As with other types of employment, citizens will not be allowed to become actors since this is deemed to be harmful to their pursuit of aretê. Slaves and foreigners will be hired to perform in this capacity. "Only the "good" may write comedies," as Nightingale indicates, "presumably because they alone will use ridicule correctly." 86 Anyone who writes a comedy for Magnesia (and he appears to be referring to citizens only here) must be over the age of fifty and must have been granted the approval of the archôn for Education 
$(829 \mathrm{c}-\mathrm{d}, 936 \mathrm{a}-\mathrm{b})$. Aspiring authors must also have attained some official esteem in the eyes of the city before they will be permitted to air their artistic visions $(829 \mathrm{c}-\mathrm{d})$.

As concerns the genre of drama in general, the Athenian Stranger states that "no serious attention should be granted to it nor should any free man or woman be seen learning it" for purposes of imitation. ${ }^{87}$ Citizens who choose to do so must be mindful of public scrutiny. They would probably not be expected to take their dramatic interests too seriously except insofar as they produce an officially acceptable and appropriately didactic script. Their style of dramatic composition must be particularly virtuous. ${ }^{88}$ One then wonders whether any of the Magnesians would have the inclination to compose drama. While the Athenian Stranger does allow for this eventuality, he is insistent that comedies must "never be allowed to ridicule any of the citizens, either in words or by way of mimêsis, whether it be with or without passion." 89 This reflects a comparable argument in the Republic in which the acting of such roles fosters the behaviors, in both actors and spectators, which are found in the persons being imitated (395c-397e). Neither should an audience derive too much pleasure from Magnesian stage productions. The "correct and laudable species of pleasure" will result simply from artistic representations of moral truth such as in the dramatic portrayal of virtuous individuals. $9 \circ$ Only noncitizens or purely fictional characters that have no discernible analogues in Magnesia may be subject to comedy's piquant wit. Even these are required to be moderate and mockery will not be permitted at all in comedy. Magnesian comedies might end up being similar to the later Satires of the Roman poet Horace, whose dry and largely apolitical character was designed "to win acceptance in the face of conservative taste. $" 9 \mathrm{I}$

Plato distrusted poets because they told lies and whipped up irrational emotions. $9^{2}$ Even so, as we have seen, he has revised his views to a point in the Laws-this time keeping the poets on a tight leash. The Athenian Stranger indicates 
I30 PLATO'S PUPPETS OF THE GODS

that some poetic works of tragedy and serious drama may be acceptable so long as they do not teach harmful lessons that might destabilize the Magnesian peace. $93 \mathrm{He}$ has composed some lines to answer any would-be dramatic performers seeking a stage in Magnesia:

Most excellent of strangers, we ourselves, to the best of our ability produce tragedy altogether the fairest and the best; indeed all our constitution has been framed as a representation of the most beautiful and best life that, in reality, we assert to be the truest tragedy. 94

This preamble to the law may be just another "fable," a paramyth designed to back up state policy as being for the benefit of the populace.95 But it appears to serve more than a purely propagandistic function. While at once excluding foreign artistic influences in much the same way as in the Republic, it may be read as a statement of belief that holds Magnesia and its laws to be the paradigmatic expression of aesthetic and philosophical virtue-a paradigm compared to which, and with regard to which, all other (lesser) works of art must be judged. Here Plato not only denies that conventional tragedy is truly serious but bestows on his own creation the designation of "serious tragedy." 96 Platonic tragedy, then, represents a triumph over traditional tragedy that evoked pity and fear; rather, it points toward what is "true and good." 97 And, as the Kallipolis in the Republic symbolized the best arrangement of the psychê in a human being, the literary representation of Magnesia in the Laws is considered the best polity achievable by human beings which imparts to them its own qualities of goodness and vice versa. The book, in some magical way, is the polis.

In a political sense, a comparison may be drawn between the Athenian Stranger's speech on the "truest tragedy" and Perikles' Funeral Oration in which the Athenian constitution was referred to as both a model, and an "education," for all the Greeks. ${ }^{98}$ Toynbee and Ober both maintain that Plato was here reacting specifically against the Funeral Oration. 99 
It should be noted, however, that he has probably not written this or any part of the Laws in direct response to a speech given fifty years prior. It is more likely that he was responding to the reception of this same speech in Thucydides and, moreover, to the views contained therein. A comparison of the Athenian Stranger's points here with passages from pseudo-Xenophon's “Old Oligarch" makes it clear enough that Plato is airing some longstanding conservative prejudices against a contemporary interpretation of Athenian democracy and the source of its strength-its navy. ${ }^{\text {Ioo }}$ This view can be traced back to other similar attitudes from the fifth century, the height of the Athenian Empire, and Plato appears to have found it sufficiently intolerable as to explicitly forbid his Magnesians from imitating Athens specifically in terms of its naval power or its imperialist ambitions. ${ }^{\text {IOI }}$

BUT PLATO'S CONCERNS with representation and imitation go further still. His conception of representation as intrinsically magical is analogous to earlier Pythagorean and Orphic positions. It follows from a Pythagorean construction, found in the fragments of Empedokles and elsewhere, that "like attracts like," where thought itself is treated as somehow fundamentally connected with the material elements about which one is thinking. ${ }^{102}$ This runs contrary to Aristotle's interpretation that cognition entails only a compositional likeness between subjects and objects. ${ }^{103}$ The principle of "like attracts like" was applied universally, as can be observed in the fragments of Philolaus on the role of heat in embryology. ${ }^{104}$ Since puppets are likenesses of real people, gods, or heroes, and Plato has already connected them to magical practices, his understanding and conceptualization of puppets appear to have been along Pythagorean lines of the "like attracts like" formulation.

There can be no doubt that Plato was directly influenced by Pythagorean philosophy. The extent to which this was the case may have been grossly underestimated. For example, J. B. Kennedy has recently discovered a new layer of 
I32 PLATO'S PUPPETS OF THE GODS

Pythagorean symbolism in the Platonic dialogues in terms of their "musical structure" which corresponds to a Pythagorean division of the musical canon into a I2-note system. ${ }^{105}$ Kennedy argues that Plato used stichometric techniques (word and line counting) to structure his dialogues so that they corresponded to this monochord scale. He also argues that Plato embedded the 7-note, Orphic scale in his dialogues as well. The full significance of this will likely become more apparent with time and greater research. At the moment, and with the aid of information technology, it is possible to observe certain "notes" in the dialogue that are more consonant or more dissonant, thus revealing, at the subtextual level, a modicum of the author's intent. This can be observed when more consonant notes fall at points in a given dialogue where the important "messages," if you will, of the dialogue are situated and more dissonant ones appear in proximity to themes/individuals/ideas with which Plato takes issue (e.g., Gorgias and the Sophists, Alcibiades, Heracleitan views). This discovery may have finally accounted for the unusual structure of the Platonic dialogues which has intrigued scholars for centuries. The subject of the more overt Pythagorean influences in Plato is too vast to be here adequately discussed, although these can be consistently observed throughout the Platonic corpus. ${ }^{\text {Io6 }}$ The clearest articulation of this connection is to be found in Aristotle's unambiguous assertion that Plato was "in most respects a follower of the Pythagoreans." 107

In keeping with the Pythagorean theme, in book 7 of the Laws, the Athenian Stranger posits a threefold definition of affection based on likeness (affection between opposites, between those that are similar, and a mixed version of the two). ${ }^{\text {108 }} \mathrm{He}$ is using here a sort of sliding scale between simple affection (philia) and erotic love (erôs), perhaps conflating the two as he has done elsewhere. ${ }^{109}$ Illustrating this, the Athenian Stranger says that "whenever each one becomes intense, we designate it erôs." пго Of its three types, the most harmonious version is said to occur in a non-physical manner 
between individuals who are most like one another in Goodness; "philia between those who are similar" is therefore deemed superior. Such a relationship, the Athenian Stranger says, is both "gentle and entails continuous, mutual affection throughout life." III This definition favors non-corporeal, "soul to soul" (Platonic) love which is considered to work best in the achievement of the ideal telos of aretê. The notion of "soul to soul" love (non-physical affection through likeness) in the Laws is also analogous to a view expressed in the fragments of Empedokles-a Pythagorean philosopher par excellence. Empedokles' central doctrine of "like being drawn to like" has been a fundamental and nearly universal principle of magical beliefs from antiquity to modern times. ${ }^{\text {I2 }}$ The attraction between "like and like" is part of a cosmological dualism which necessitates therefore a repulsion between "unlikes," which Plato also bears out in his definition. ${ }^{\text {II } 3}$ On this affinity of "likes," Empedokles wrote: "So sweet lays hold of sweet, and bitter rushes to bitter; acid comes to acid, and warm couples with warm." II4 This expression of Empedokles' theory of attraction, in spite of (or because of) its medical connotations, corresponds to Plato's second category of affection in the Laws- "between those who are similar"-which is both "gentle and has continuous mutual affection." IIs It is sometimes difficult to separate Empedokles the philosopher from Empedokles the mystic; indeed the same can be said of Pythagoras, but perhaps for them, there was no conflict between the two roles. ${ }^{\text {I }} 6$

The repulsion of opposites appears in the Athenian Stranger's disquisition on the "so-called Love" between opposites, which is described as "violent and unrestrained and most often not reciprocated." II7 This connection between Plato and Empedokles is further strengthened by the latter's doctrine of the cosmic principles of Love and Strife-part and parcel of his theory of attraction and repulsion:

For all these-sun, earth, sky and sea-are one with the parts of themselves that have been separated from them and born into mor- 
I34 PLATO'S PUPPETS OF THE GODS

tal things. And even so all things that are more adapted for mixture are like unto one another and united in Love by Aphrodite. ${ }^{\text {I } 8}$ Those things, again, that differ most in origin, in mixture, and in their forms imprinted upon each are most hostile, being altogether unaccustomed to unite and very sorry by the bidding of Strife, since it has wrought their birth. ${ }^{\text {I } 9}$

In Empedoklean / Pythagorean tradition, as well as in many (especially Orphic) magical operations throughout the ancient world, it was the interactions of the prime, operative forces of Love (attraction) and Strife (repulsion) which were seen, from Hesiod's time onwards, as governing the underlying functions of the universe. ${ }^{\mathrm{I} 20}$ Theophrastus $(372-287 \mathrm{BC})$, a foremost disciple of Aristotle, took lines 6-7 of the above fragment to indicate how pain results from the interaction of opposites-not unlike the ensuing Strife that Plato considers to result from relationships between people of opposite character. $^{\text {22I }}$ The activity of Love and Strife is similar to, and a principal illustration of, their cosmic functions. ${ }^{\mathrm{I} 22}$ Parts of the four universal elements are said to be mixed with each other in mortal things. Love and Strife are active in each. Even after the initial creation, some things can still be combined or re-combined and so Love makes them similar to each other so that they "want" to come together. ${ }^{223}$ Other material things cannot come together harmoniously and they have a wretched existence due to the effects of Strife.

The Pythagoreans maintained, in keeping with Dionysiac and Orphic traditions, that there were certain actions which one could undertake to effect a change in the process of metempsychosis. Plutarch, himself an initiate of the Eleusinian Mysteries and priest of Apollo at Delphi, reported that the legends of the sufferings of Dionysos convey the meaning of palingenesis or rebirth. ${ }^{\mathrm{I} 24}$ Thus, perhaps, Plato's fondness for Dionysiac manias. The solution for Empedokles, and also for Plato, comes through the attainment of wisdom. This appears to be the key to unlock the cycle of perpetual expiatory rebirth for "blessed is the one who has gained the riches of Divine Wisdom" and likewise 
"wretched is he who has a dim opinion of the gods in his part." ${ }_{25}$ Consider Meno 97d ff., where we are told that opinions are inferior to knowledge as a guide for one who would be wise, alongside Plato's distinction between intellection and opinion at Republic 534a. So too ought his statements at Republic 479e ff. (and many other places besides) be taken into account in light of Pythagorean influences when the literary Socrates describes the difference between knowledge of "the Beautiful" and "the Just" as opposed to mere opinion about these. One who lacks true Knowledge may "have opinions about all things, but know nothing of the things about which they opine.” 26 This Platonic correspondence with Pythagoreanism is strengthened by Empedokles' indication that "it is not possible for us to set God before our eyes, or to lay hold of him with our hands," which is the manner by which most people are persuaded-through opinion and sensation. ${ }^{\text {I27 }}$

In Book Io of the Laws, the Athenian Stranger engages in a fairly familiar Platonic proof of the existence of soul and its immortality. He also distinguishes the several types of motion which can occur in nature until he arrives at that which "moves itself." ${ }_{228}$ Whenever this motion manifests itself "in earth, water, or fire-diversely or in combination ... we call it alive." 29 The Athenian Stranger indicates that names and definitions both refer to a particular "being (tên ousian)" and that he is seeking a definition for the "being" whose name is "soul." " 30 That which proves to be alive can be said to have a soul. The Athenian Stranger concludes that, because it can move itself, therefore the (reductive) definition for soul is "that which itself has the power to set itself into motion." ${ }_{33}$ (This derives in part from Thales of Miletus who argued that magnets must have a soul since they can move iron. Magnets were of special interest to the Pre-Socratics, including Empedokles, for whom they figured prominently in his formulation of magical phenomena. $)^{132}$

The immortality of the soul is manifest in the fact that soul is prior to body and that soul is part of (and emanates from) 
I36 PLATO'S PUPPETS OF THE GODS

a universal soul which is the prime cause of all motion and agency-including magical agency. ${ }^{\mathrm{I}} 33$ This is a consistent and well-discussed view throughout the Platonic corpus. I34 The Athenian Stranger in the Laws reasons that "Soul is the cause (aitia) of goodnesses and of evils, of beautiful things and of shameful things, of justices and injustices and of all things opposed to these-would we not be correct to posit soul itself as the cause of everything?" 135 The self-moved motion of the universal psychê is said to be manifest in the movements of stars and planets in the heavens. The Athenian Stranger later insists that the guardians of his next-toideal state should be able to prove the existence of soul, and also of the Divine, by the same line of argument. ${ }^{\mathrm{I}}{ }^{36}$

There is a clear connection between Plato's puppets and Pythagorean likenesses being attracted to one another. Puppets are likenesses of the entities that they represent, both as the actual puppets and also, through Plato's metaphor, at the metaphysical level, by their connection with either the higher Forms or with the baser, psychical components (which presumably must also have their metaphysical analogues). In both Plato and in the Pythagorean views that we have, such likeness is seen to have a reciprocal and interactive relationship, effectively through magic. Plato's puppets may take to heart the lessons of Diotima's Birth in Beauty speech, realizing that the only true affection is that for the Good; the good in us is attracted to its rightful object, and we thereby yield to the pull of the golden cord. Or they may also fail to be attracted to its pull, perhaps lacking the Wisdom and logismos appropriate to cultivate any such attraction to the Goodperhaps lacking sufficient good within themselves?-pulled instead by the baser elements, the iron strings, to which they are more attracted. The metaphor itself operates through the principle of likeness, referring to the puppets as likenesses even further removed, but all connected through this formula of representation being somehow bound up together by magical "action at a distance." 
AS DISCUSSED AT the beginning, puppets do not move themselves-at least, not the ordinary variety. Puppets, almost by definition, are inanimate until animated. Human beings possess a psychê which is a self-moving mover, as we have seen, thus making them thaumata theion in Plato's formulation. The metaphor of puppets is somewhat obscure and perhaps deliberately so-possibly so that only those who are familiar with Platonic metaphysics will correctly interpret it according to these esoteric prescriptions. It has certainly been the tendency of the Laws to reference the more complex metaphysical ideas of the Platonic corpus without going into them in any great detail, as if expecting the "right" reader to know the cipher. Again, presumably those who have read Plato's other "manuals of philosophy," and participated in dialectics whereby the Many are shown to be One, will ascertain in it the Pythagorean doctrine of "like attracts like," whereas others who are deprived of these teachings will not.

The Puppets of the Gods metaphor is laden with complex significance, as I have tried to demonstrate here. We have seen that the cultural context of puppetry in Ancient Greece entailed the mystical and the magical. It is also clear from Plato's writings, informed by Pythagorean views, that he considered symbolic representations to possess magical qualities through their likenesses to other things, both mundane and divine. This would appear to be a consequence of their partaking of the Forms, although it is never fully stated in precisely those terms. If Plato believed that a wax manikin could somehow be used to produce a negative, magical effect upon an individual through the magic of representation, then puppets representing gods, heroes, or ordinary people could also be considered to produce a real-world effect of some type as well. A mundane puppet may be imbued with such powers, but "divine marvels" are at least an order of magnitude higher on the scale of being. What do "puppets of the gods" then represent? They would seem to be no less than the physical manifestation of the psychê, itself resident in the realm of the Forms, being projected into the world of 
I 38 PLATO'S PUPPETS OF THE GODS

perceptual phenomena. They are "divine" in the sense that individual psychai are each "at one" in some sense with the universal psychê. In other words, for Plato, the human "puppet," through likeness, action at a distance, and particularly with its "golden $\mathrm{c}(\mathrm{h})$ ord," represents no less than the supreme divinity itself and, as such, is a marvel with which one should not trifle.

\section{NOTES}

I. George B. Hussey, "The More Complicated Figures of Comparison in Plato," The American Journal of Philology, I7.3 (г 896), 329-46.

2. Plato, Laws, R. G. Bury, trans. and ed., Loeb Classical Library (Cambridge, MA and London I994), 644d8-9.

3. See Dorothea Frede, "Puppets on strings: Moral psychology in Laws Books I and 2," I 20, in Christopher Bobonich, ed., Plato's Laws: A Critical Guide, (Cambridge 2010), I08-26, for the notion that logismos here is to be distinguished from nous per se.

4. Plato, Laws $644 \mathrm{dI}_{-3}$, unless otherwise specified, all translations are my own.

5. Plato, Laws 644d7-645a3.

6. Hussey, "The More Complicated Figures of Comparison in Plato" (note I), 343 .

7. Henry George Liddell and Robert Scott, revised and ed. by Sir Henry Stuart Jones, A Greek-English Lexicon, $9^{\text {th }}$ edition (Oxford 1994), s.v. thauma.

8. Plato, Laws $645 \mathrm{bi}-3$.

9. Hesiod, Works and Days in The Homeric Hymns and Homerica, Hugh G. Evelyn-White, ed. and trans., (Cambridge, MA and London I9I4), I 74 ff. Walter Burkert connects the functions of Love and Strife with Hesiod as well, for which see note I 20 below.

Io. See Susan Sauvé Meyer, "Pleasure, Pain, and 'Anticipation' in Plato's Laws, Book I," Presocratics and Plato: a Festschrift in Honour of Charles Kahn, R. Patterson, V. Karasmanis and A. Hermann, ed., (Las Vegas 20I 2), 3II-28.

I r. M. W. Dickie, "Magic in Classical and Hellenistic Greece," A Companion to Greek Religion, Daniel Ogden, ed., (Chichester, West Sussex 2007), 357-70.

I 2. Herodotus, Histories, A. D. Godley, ed. and trans. (Cambridge, MA I920), 2.48.

I3. Dickie, "Magic in Classical and Hellenistic Greece" (note II), $357-59,366$. 
I4. Derek Collins, "Nature, Cause, and Agency in Greek Magic," 4I, Transactions of the American Philological Association (1974-), I33.I (Spring 2003), I7-49.

I 5 . Aristotle, On the Movement of Animals, A. L. Peck and E. S. Forster, trans. and ed., Parts of Animals, Movement of Animals, and Progression of Animals (Cambridge, MA 1968), 7.3

I6. Julia Annas, “Changing from Within: Plato's Later Political Thinking," Corbett Lectures, presented at the University of Cambridge, I7 November $201 \mathrm{I}, 8$.

I7. Sylvia Berryman, "The Puppet and the Sage: Images of the Self in Marcus Aurelius," Oxford Studies in Ancient Philosophy 38 (Summer 2010), I87-2I9.

I 8. Berryman, "The Puppet and the Sage" (note I7), I89-96, 218-I9.

19. Liddell, Scott and Jones, A Greek-English Lexicon, s.vv. neuron and mêrinthos.

20. Plato, Laws 700b, 722e, 734e, 775b, 799e. See too S. Todd and P. Millett, "Law, Society and Athens," I 2 in Nomos: Essays in Athenian Law, Politics and Society, P. Cartledge, P. Millett and S. Todd, eds. (Cambridge I990), I-I 8 .

2I. Euclid the Elements, J. L. Heiberg, ed. (Leipzig I $883_{3}$-1888), Book 6, Definition 3.

22. See Michael Byrom, The Puppet Theatre in Antiquity (Bichester 1996). Byrom thinks these were operated from above the stage. Hans Richard Purschke, Die Anfänge der Puppenspielformen und ibre vermutlichen Ursprünge (Bochum, North Rhine-Westphalia I979), thinks they were operated horizontally, on the stage, perhaps behind a curtain.

23. Claudius Galenus, De usu partium, G. Helmreich, ed., 8 vols. [Books I-8] (Leipzig I907), I.I7.

24. Homer, Odyssey 7.87, Iliad I 8.37 I ff.

25. Pindar, "Olympic Ode 7," The Odes of Pindar including the Principal Fragments, Sir John Sandys, introd. and trans. (Cambridge, MA. and London I937), 5I-54.

26. Plato, Euthyphro IId and Meno $97 \mathrm{~d}$.

27. Aristotle, De Anima 406bi 5-22.

28. Pliny, Naturalis Historia, Karl Friedrich Theodor Mayhoff, ed. (Leipzig I906), 34.I 48

29. See Noel Sharkey, "A programmable robot from AD 60," New Scientist, 26I I (July 4, 2007) and Marie Boas, "Hero's Pneumatica: A Study of Its Transmission and Influence," Isis, 40.I (Feb. I949), 38-49; and see too Greek and Roman technology: A Sourcebook. Annotated Translations of Greek and Latin Texts and Documents, John W. Humphrey, John P. Oleson, and Andrew N. Sherwood ed., (London and New York I998), 66-67.

30. M. W. Dickie, "Mimes, Thaumaturgy, and the Theatre," 60I, The Classical Quarterly, New Series, 5 I.2 (200I), 599-603. 
I4O PLATO'S PUPPETS OF THE GODS

\author{
3I. Plato, Laws 659di-4. \\ 32. Plato, Laws 803е I-4. \\ 33. Plato, Laws 796b3-c2.
}

34. The Kuretes were mountain spirits who protected the infant Zeus, represented in art as dancing youths. On the armed drama of the Dioskuri, see Athenaeus The Deipnosophists, Charles Burton Gulick, ed. and trans. (Cambridge, MA and London I927), 4, I84ff. The Augustan scholar Dionysius of Halicarnassus, de Comp. 22, de Dem. 39, in C. M. Bowra, Pindar (Oxford 1964), I93, 363, says that Athenians invented their armored dance to celebrate the triumph of the gods over the giants. $\mathrm{H}$. Jeanmaire, Couroi et Courêtes: Essai sur l'éducation spartiate et sur les rites d'adolescence dans l'antiquité hellénique (Lille I939), 42 I ff. refers to the Kretan dances and other such institutions as a kind of "club masculin" designed to impart martial values. See too Iréne Aghion, Claire Barbillon and François Lissarrague, ed., Gods and Heroes of Classical Antiquity, Leonardo N. Amico, trans. (Paris and New York I996), I92-94.

35. Plato, Laws 8 I 5 d.

36. Plato, Laws 8 I4-16e.

37. Aristotle, Politics W. D. Ross, ed. (Oxford I957) 2.6.I265a30-35.

38. Plato, Republic in Platonis Opera, John Burnet, ed. (Oxford I903), $398 \mathrm{cff}$.

39. See Desmond Lee, ed. and trans., Plato: The Republic, ${ }_{2}^{\text {nd }}$ ed. (Middlesex, UK I974), 258.

40. See K. R. Moore, "Was Pythagoras ever really in Sparta?," Rosetta: Papers of The Institute of Archaeology and Antiquity, 6 (2009), I-25.

4I. Plato, Laws 804 bi-4.

42. Terence Irwin, "Morality as Law and Morality in the Laws," I07-8 in Plato's Laws: A Critical Guide, Christopher Bobonich, ed., (Cambridge 2010), 92-108.

43. Education will "enchant" or cast spells on the souls of the young (Laws 659c9-66oa8, 664 b3-c2). On the preambles (paramythia), see Laws 773 $\mathrm{d}_{4}-\mathrm{e}_{4}, 8$ I $2 \mathrm{~b}_{9}-\mathrm{c}_{7}, 84$ ob9-c3, 903a Io-b2.

44. Plato, Laws 966ci-9.

45. Thomas Gould, Platonic Love (London I963), I39.

46. For immortality of the soul in Plato see also Letter VII, 334e; Meno, 8 I b, 85 c; Phaedo, 72e-76, 8 5e-9I ff., I05 ff., I07c; Republic, $498 \mathrm{c}, 608 \mathrm{c}$ ff.; Timaeus, 4Ic ff., 69c; Symposium, 208c, amongst others.

47. John M. Rist, "Plato and Professor Nussbaum on Acts 'Contrary to Nature," 69, Studies in Plato and the Platonic Tradition, Mark Joyal, ed. (Aldershot 1997), 65-79.

48. Plato, Laws 237d6-9; see A. W. Price, Love and Friendship in Plato and Aristotle (Oxford 1989), 6o; see too Moore, Sex and the Second-Best City, chapter 4 , on doxastic self-mastery.

49. Plato, Phaedrus 237d6-e2. 
50. Plato, Phaedrus 237e2-238a2.

5I. Plato, Phaedrus 238b9-c4.

52. Price, Love and Friendship, 6I.

53. See too Plato, Lysis 2 I 2a ff. on these rival impulses.

54. Christopher Bobonich, Plato's Utopia Recast: His Later Ethics and Politics (Oxford 2002), 298. As he points out, kôphos can mean either "deaf" or "senseless." In tragedy, a kôphon prosôpeion is a mute figure. But to make the dark horse either mute or senseless seems in conflict with the earlier description of him having a conversation with the other horse and charioteer. Of course, this is only a fable.

55. Plato, Laws $837 \mathrm{~b} 8-\mathrm{c} 3$

56. Plato, Phaedrus 239b.

57. Plato, Phaedrus 265a-266a ff.

58. See Gregory Vlastos, Platonic Studies (Princeton I973), 27. n.80.

59. J. Pieper, Enthusiasm and Divine Madness, Richard and Clara Winston, trans. (New York I964), 49 ff.

60. See Theognis, The Works Of Hesiod, Callimachus And Theognis, J. Banks, trans. (Whitefish, Montana 20II), 509-IO, 837-40 for a similar statement of moderation in drinking. Laws 666a-d details these legal regulations of age. See F. Lissarrague, The Aesthetics of the Greek Banquet: Images of Wine and Ritual (Un Flot d'Images), A. Szegedy-Maszak, trans. (Princeton, NJ I990), Io; and E. Belfiore, "Wine and Catharsis of the Emotions in Plato's Laws," Classical Quarterly 36 (I986) 42I-37, 429, on the promotion of drunkenness and singing amongst Magnesia's elderly which parallels the medical operation of purgation of the body.

6I. See Leon Golden, Aristotle on Tragic and Comic Mimesis (Atlanta, GA I992), I2-I3; and E. Belfiore, "Wine and Catharsis" (note 60), $42 \mathrm{I}-37$, for a discussion of the use of wine in the Laws as a means to train emotions through a kind of forced cathartic activity.

62. Plato, Laws $647 \mathrm{~d}_{3}-4$. The subjects should become "fearless" in the face of pleasure (648b9-c3). Compare with Xenophon, Constitution of the Lacedaimonians, E. C. Marchant, ed. Xenophontis opera omnia, 5 vols. (Oxford I969), 3.5, for a similar goal set by the Spartans.

63. Plato, Laws 644ci2-645c8.

64. Plato, Laws 671d9-e3.

65. Plato, Sophist 233 a.

66. Plato, Republic 364c.

67. Plato, Republic 602d; see too Scott Cutler Shershow, Puppets and "Popular" Culture (Ithaca, NY and London I995), I7-I 8.

68. Hussey, "The More Complicated Figures of Comparison in Plato" (note I), 333 .

69. Plato, Laws 933 a.

70. See Plato, Republic 364b-e and Laws 909b. 
I42 PLATO'S PUPPETS OF THE GODS

7I. E. R. Dodds, "Plato and the Irrational," The Journal of Hellenic Studies, 65 (1945), I6-25, 22; see Ulrich von Wilamowitz-Möllendorf, Glaube der Hellenen, Band II (Berlin I93I), 250.

72. Shershow, Puppets and "Popular" Culture (note 67), I 8.

73. Plato, Cratylus 425d; Clitophon $407 \mathrm{a}$

74. Tragedy (Philebus 48a) is said to produce mingled pleasures and pains and (Republic 602b) therefore not to be taken seriously; see too Republic 394d ff.; Laws 8I $6 \mathrm{~d}$ ff.; and note 75 below.

75. Sabina Lovibond, “An Ancient Theory of Gender," Women in Ancient Societies: An Illusion of the Night, L. Archer, S. Fischler and M. Wyke, eds. (London I994), 89-IOI, 96. His narrator disdainfully remarks at Laws $658 \mathrm{~d}$ that "educated women," as with the common people, regard tragedy as the best form of entertainment.

76. Noam Chomsky, Interview in The Whole Shebang, $\mathrm{BBC}_{2}$, aired I April 2002.

77. Golden, Aristotle on Tragic and Comic Mimesis (note 6I), 44.

78. See Plato, Republic 398a-b

79. Plato, Phaedrus 275a-b; see Andrea Wilson Nightingale, "Liberal Education in Plato's Republic and Aristotle's Politics," Education in Greek and Roman Antiquity, Yun Lee Too, ed. (Leiden 200I), I33-74; John Hesk, Deception and Democracy in Classical Athens (Cambridge 2000), I59-63, I5 I ff.; and Jacques Derrida, Dissemination, Barbara Johnson, trans. (Chicago I98I), s.v. "Plato's Pharmacy."

80. Andrea Wilson Nightingale, "Plato's Lawcode in Context: Rule by Written Law in Athens and Magnesia," Classical Quarterly, 49.I (I999), IOO-I22, I03.

8 I. See Derek Collins, "Nature, Cause, and Agency in Greek Magic" (note I4), I8-r9.

82. Plato, Laws $8 \mathrm{I}_{6 \mathrm{~d}} 3 \mathrm{-I} 3$.

83. Andrea Wilson Nightingale, Genres in Dialogue: Plato and the Construct of Philosophy (Cambridge I997), I75 n. Io.

84. Plato, Republic 396a

85. Golden, Aristotle on Tragic and Comic Mimesis (note 6I), 44.

86. Nightingale, Genres in Dialogue (note 83), I85.

87. Plato Laws 8 I 6e8-i I.

88. See Stephen Halliwell, Aristotle's Poetics (London I998), 64 ff. for comparisons with Aristotle's Poetics.

89. Plato Laws 935e 5-6; compare Aristotle Nicomachean Ethics, J. Bywater, ed. (Oxford I 894), I I 28 a 20 ff. and Politics, W. D. Ross, ed. (Oxford I957), I336b2 ff.

90. Halliwell, Aristotle's Poetics (note 88), 63.

9I. Niall Rudd, Horace: Satires and Epistles (London I997), 24.

92. A. D. Nuttal, Why Does Tragedy Give Pleasure? (Oxford 1996), 5; 
compare Plato Republic 398a.

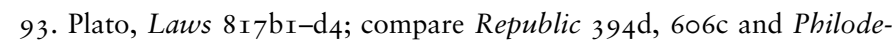
mus $48 \mathrm{a}$.

94. Plato, Laws 8I 7a9-b6.

95. See Hesk, Deception and Democracy (note 79), I 57-62, I36, for the Athenian Stranger's employment of "noble lies" as characteristically reflective of Spartan propagandistic policies more so than Athenian; and see K. R. Moore, "Platonic Myths and Straussian Lies: The Logic of Persuasion," Polis: The Journal for Ancient Greek Political Thought 26.I (2009), 89 -II 5 .

96. Nightingale, Genres in Dialogue (note 83), 88.

97. Golden, Aristotle on Tragic and Comic Mimesis (note 6I), 6I; see Suzanne Saï, La faute tragique. (Paris I978), 5 Io, who recognizes this particular tack of Platonic mimêsis in her discussion of his use of hamartia, saying, "Ainsi, la faute tragique, avec ses ambiguités et ses contradictions, n'a plus de réalité aux yeux du philosophie. Elle n'est jamais qu'une illusion, un fantôme funeste qui ne peut qu'abuser les insensés. Il faut donc la banner de la cité avec son créateur."

98. Thucydides, Historiae, 2 vols. (Oxford I942), 2.35.

99. Josiah Ober, Political Dissent in Democratic Athens: Intellectual Critics of Popular Rule (Princeton, NJ I998), 45, I43; and A. J. Toynbee, Study of History, 3 vols. (Oxford I972), 90-92.

Ioo. C. MacDonald, "Plato, Laws $704 \mathrm{a}-707 \mathrm{c}$ and Thucydides II.35-46," Classical Review 9 (1959), ro8-9; and see too Philip A. Stadter, ed. with intro., The Speeches in Thucydides: A Collection of Original Studies With a Bibliography (Chapel Hill, NC 1973).

гог. Plato, Laws 704b ff.

I02. Rachana Kamtekar, "Knowing by Likeness in Empedocles," Phronesis 54 (2009) 21 5-58, 222-23.

I03. Aristotle de Anima, R. D. Hicks, trans. and intro. (Cambridge I907), I.2; and Metaphysics, W. D. Ross, ed. (Oxford I924), 3.4.

I04. Carl A. Huffman, Philolaus of Croton: Pythagorean and Presocratic (Cambridge I993), 88.

I05. See J. B. Kennedy, The Musical Structure of Plato's Dialogues (London 20I I). See too J. B. Kennedy, "Plato's Forms, Pythagorean Mathematics, and Stichometry," Apeiron: A Journal for Ancient Philosophy and Science (43.I) 2010, I-32; and see Theon of Smyrna, Mathematics Useful for Understanding Plato; translated from the I 892 Greek/French edition of J. Dupuis by Robert and Deborah Lawlor and edited and annotated by Christos Toulis and others; with an appendix of notes by Dupuis, a copious glossary, index of works, etc. (San Diego 1979).

106. See Walter Burkert, Lore and Science in Ancient Pythagoreanism, Edwin L. Minar Jr., trans. (Cambridge, MA I972), 8, 27, 57-7I, 79-83, 85, 92, 20I, 37I ff.; see too Peter Kingsley, Ancient Philosophy, Mystery, and Magic: Empedocles and the Pythagorean Tradition (Oxford 1995), 
I44 PLATO'S PUPPETS OF THE GODS

88-I I 5, I3 I-32; and John Burnett Early Greek Philosophy, $3^{\text {rd }}$ ed. (London I920), 22I-99, for more on Pythagorean connections in Plato. Leonid Zhmud, "From the Ancient to the New Doxography: Aristotle, Theophrastus and Diels (and beyond)," presented at the University of St. Andrews' School of Greek, Latin and Ancient History's Class Seminar, I3 April 200I, has pointed out that Kingsley's criticism of Diels' doxographic placement of Empedokles, along with his particular reformulation of Pythagorean history and philosophy, are not without their faults. He has likewise questioned Burnett's approach to Diels' Doxographici Graeci. Nonetheless, Zhmud freely acknowledges the profound Pythagorean influence on Plato. And see note 107 below.

107. Aristotle, Metaphysics A.5.987azo

ı08. Plato, Laws 837c3-di.

I09. Plato's narrators have done this before in the Lysis (22 I b7-8) where, as David Konstan, Friendship in the Classical World: Key Themes in Ancient History (Cambridge I997), 73, writes, "Socrates casually collapses the differences between philia, eros, and epithumia (cf. Laws 8.837ar), and the discussion moves freely among cases of parental affection, erotic attraction, attachment between friends, and even the appeal of inanimate objects."

I Iо. Plato, Laws 837a8-9.

I I I. Plato, Laws $837 \mathrm{~b}_{3}-4$.

II2. W. Kranz, Empedokles: Antike Gestalt und romantische Neuschoepfung (Zurich 1949), 62, 91.

I I3. Plato, Laws 837 b2-3.

I I4. Quoted in Hermann Diels, Die Fragmente der Vorsokratiker, Io ${ }^{\text {th }}$ ed., W. Kranz, ed. (Berlin I95 I-52), fr. 90; also see H. Ritter and L. Preller, Historia Philosophiae Graecae, $8^{\text {th }}$ edition (Gotha I 898), I66h; and Empedocles: the Extant Fragments, M. R. Wright, ed. (New Haven, CT I98I), 75. See also Plutarch, Quaestiones convivales, Plutarch Moralia, Gregorius N. Bernardakis, ed. (Leipzig I892), 663; and Macrobius, Saturnalia, Ludwig von Jan, ed. (Quedlinburg and Leipzig I852), 7.5.17. Both Plutarch and Macrobius locate this passage in the context of medicine (see Theophrastus, De sensibus in Diels, Die Fragmente der Vorsokratiker, I2; and Aristotle, De Anima 4I6a30). The medical aspects of this theory of attraction were not lost upon Plato (Phaedo 96a-b).

I I 5. Plato, Laws $837 b_{3}-4$. On the subject of "like to like" in Plato, cf. Gorgias 510b; Laws 837a; Lysis 21 4a ff., 21 8b, 222c; Parmenides (a thoroughly Pythagorean dialogue) I29a, I39e ff., I47c ff., I6rb ff., and "unlike," Parmenides I27e, I29a ff.; Republic 329a, 425c; "like," Symposium I95b, and "unlike" see note below.

II6. Pythagoras, was reported to have been an initiate of Eleusis, the Cabeiric mysteries, the mysteries of Crete and of foreign places, according to Diogenes Laertius, Lives of Eminent Philosophers, R. D. Hicks, ed. (Cambridge, MA I972), 8.2. 
I 7. Plato, Laws $837 \mathrm{~b} 2-3$; and compare also the quasi-scientific speech of Eryximachos in the Symposium (I86b) in which we hear of the stormy affections between opposites.

I I 8. Plato has, not surprisingly, made this association with Love and Aphrodite in his own philosophy, for which see Phaedrus, 242d, 265b; Symposium, I8od, I8Ic, $203 \mathrm{c}$.

I I9. Diels, Die Fragmente der Vorsokratiker, fr. 22; and see Ritter and Preller, Historia Philosophiae Graecae (note II4), I66c; Wright, Empedocles (note II4), 25.

I 20. Elements of Empedokles' theory of Strife can be traced back to Hesiod, on which see Walter Burkert, The Orientalizing Revolution: Near Eastern Influences on Greek Culture in the Early Archaic Age (Cambridge, MA I992), 9I-92. On Empedokles' principles of Love and Strife, see Diels, Die Fragmente der Vorsokratiker, fr. BI 7.7-8, 20.4, 21.7-8, 26.5-6, 109.3. On the relationship between these principles and "sympathies" and "antipathies" in ancient Greek magic, ritual and alchemy, see J Needham, Science and Civilisation in China, (Cambridge I954-84), 2.39-40.

I2I. Theophrastus, De sensibus in Diels, Die Fragmente der Vorsokratiker, $\mathrm{I} 6$.

I22. M. R. Wright, Empedocles: the Extant Fragments (note II4), I92. I23. Wright, Empedocles (note II4), I93.

I24. Plutarch, De esu carnium, in Plutarch Moralia, Bernardakis, ed. (note I I4), I.996c.

I25. Diels, Die Fragmente der Vorsokratiker, I32; Ritter and Preller, Historia Philosophiae Graecae (note I I4), I79.

I26. Plato, Republic $478 \mathrm{~b}-\mathrm{c}$.

I27. Diels, Die Fragmente der Vorsokratiker, I33.

I 28. Plato, Laws $894 \mathrm{~b}$. Aristotle, as Plato likely was aware, denied that the soul moved in space except when the body which contained it moved; nevertheless, he agreed that the soul could indirectly move itself through space, kata sumbebe kos by causing its body to move with itself inside (De anima $408 \mathrm{a} 30 \mathrm{ff}$.). This argument, begun at 894e and developed around $896 \mathrm{aff}$., was often quoted, and highly regarded, by John Stuart Mill in his Autobiography (Raleigh, NC I999), I46. It is considered that Thales of Miletus was the first to define psychê as "what is always moved or selfmoved" and almost all other thinkers followed him in this (Diels, Die Fragmente der Vorsokratiker, fr.II A $22=$ Aristotle, De Anima I.2.405al9-2I88). Yet see Diels, Die Fragmente der Vorsokratiker, Anonyme Pythagoreer B, Ia (I.449, 24).

I 29. Plato, Laws 895C4-7. Empedokles seems to have considered these to be gods (Diels, Die Fragmente der Vorsokratiker, 3 I A 32 = Aēt. I.7.28).

I30. Plato, Laws 895 d ff. E. B. England, ed., Plato: The Laws, vols. I-II. (Manchester I92I), 472, in his commentary on Laws $895 \mathrm{~d}_{4}$, wrote of ousia that "the ordinary citizen only knew this word in the sense of property," but it was the Pythagoreans who had attributed to it the philosophical 
I46 PLATO'S PUPPETS OF THE GODS

meaning of "reality" or "existence." Likewise, the notion that names and definitions both equal the same thing has the quality of Euclid's "things which are equal to the same thing are equal to each other." Plato has employed ousia before in a metaphysical sense referring to the eternal "being" and the world of ideas, see Letters VII, 342a ff. For an explanation of the "definition" of a term, see Theaetetus 201е-202c.

I3 I. Plato, Laws 895ero-896a2; tên dunamenên autên autên kinein kinêsin.

I32. Collins, "Nature, Cause, and Agency in Greek Magic" (note I4), 37.

I33. See Collins, "Nature, Cause, and Agency in Greek Magic" (note I4), 38 .

I34. For a specific "proof" of the primacy of soul over body, cf. Meno $8 \mathrm{Ib}$ ff. That the soul is divine, see Laws $726 \mathrm{ff}$.; and on the oneness of the Divine Soul, see Epinomis 98 I b.

I35. Plato, Laws $896 \mathrm{~d}_{5}-8$.

I36. Plato, Laws 966c-967a. 